\title{
Abortion due to infection with Chlamydia psittaci in a sheep farmer's wife
}

\author{
F W A JOHNSON, B A MATHESON, H WILLIAMS, A G LAING, V JANDIAL, \\ R DAVIDSON-LAMB, G J HALLIDAY, D HOBSON, S Y WONG, KATHERINE M HADLEY, \\ MARGARET A J MOFFAT, R POSTLETHWAITE
}

\begin{abstract}
A farmer's wife who had helped with lambing aborted spontaneously in March after a short febrile illness in the 28th week of her pregnancy. She developed disseminated intravascular coagulation post partum with acute renal failure and pulmonary oedema. Recovery was complete after two weeks of hospital care. A strain of Chlamydia psittaci, probably of ovine origin, was isolated from the placenta and fetus. The patient's serum showed rising titres of antibody against chlamydia group antigen; the placental and fetal isolates; and a known ovine abortion, but not a known avian, strain of $C$ psittaci. IgG against both ovine abortion and enteric strains of $C$ psittaci was detected, but IgM against only an abortion strain was detected. Histological examination showed pronounced intervillus placentitis with chlamydial inclusions in the trophoblast but no evidence of fetal infection or amnionitis. Laboratory evidence of chlamydial infection was found in an aborting ewe on the farm in January and in remaining sheep and lambs in July.

Doctors should recognise the possible risk to pregnant women in rural areas where chlamydial infections in farm animals are widespread.
\end{abstract}

Department of Veterinary Preventive Medicine, Veterinary Field Station, University of Liverpool, Neston, Wirral, Merseyside

F W A JOHNSON, FIMLS, MIBIOL, research fellow

Microbiology Laboratory, Raigmore Hospital, Inverness B A MATHESON, FIMLS, chief medical laboratory scientific officer $\mathrm{H}$ WILLIAMS, MD, consultant microbiologist

Hopeville, Tarves, Ellon, Aberdeenshire AB4 0JY

A G LAING, MB, DOBSTRCOG, general practitioner

Aberdeen Maternity Hospital, Aberdeen AB9 2ZA

V JANDIAL, MS, MRCOG, consultant obstetrician and gynaecologist

Intensive Therapy Unit, Aberdeen Royal Infirmary, Aberdeen R DAVIDSON-LAMB, MB, FFARCS, consultant anaesthetist

Veterinary Investigation Laboratory, North of Scotland College of Agriculture, Mill of Craibstone, Aberdeen

G J HALLIDAY, BVMS, MRCVS, veterinary investigation officer

Department of Medical Microbiology, University of Liverpool, Royal Liverpool Hospital, Liverpool L69 3BX

D HOBSON, MD, FRCPATH, reader

Medical School, University of Aberdeen, Aberdeen AB9 2ZD $S$ Y WONG, MB, DOBSTRCOG, lecturer in pathology

KATHERINE M HADLEY, BSC, MB, clinical lecturer in bacteriology

MARGARET A J MOFFAT, BSC, PHD, senior lecturer in bacteriology

$R$ POSTLETHWAITE, BSC, MD, professor of virology

Correspondence to: Professor R Postlethwaite.

\section{Introduction}

The view that chlamydiae may cause human abortion ${ }^{1}$ has been supported by inferential reports based on epidemiological or serological information, which suggest that strains of Chlamydia psittaci associated with enzootic ovine abortion may infect pregnant women, particularly during the lambing season, and cause abortion. ${ }^{2}{ }^{3}$ We describe the first reported case, in which this association was confirmed by isolation and identification of the causative organism from the placenta and fetus and serological and histopathological evidence of infection. Further clinical, epidemiological, microbiological, and histopathological work is necessary and is in progress.

\section{Case report}

On 29 February 1984 a previously healthy 28 year old farmer's wife presented in the 28 th week of her second pregnancy with fever, nausea, vomiting, and severe headache. She had a temperature of $37.4 \mathrm{C}$ but no other abnormality on examination and urine testing. Treatment was not prescribed, and the symptoms gradually improved. On 4 March she went into spontaneous labour and delivered a stillborn boy two hours later. Postpartum haemorrhage occurred. Ergometrine maleate with synthetic oxytocin was administered, and she was transferred to Aberdeen Maternity Hospital.

On admission she had tachycardia, fever, slight hypotension, and an inflamed pharynx. Vaginal blood loss was minimal. Her general condition deteriorated despite the administration of intravenous fluids and ampicillin. She became oliguric, developed features of septicaemic shock, and was transferred to the intensive therapy unit at the Aberdeen Royal Infirmary on 5 March. She had a normal temperature, but pulmonary oedema and some hepatosplenomegaly were present. Radiographs of her chest showed severe bilateral pulmonary oedema, which settled basally with transient pleural effusions. An ultrasonic scan showed a bulky uterus but no evidence of retained products. The antimicrobial regimen was changed to penicillin, cloxacillin, and cefoxitin; diuretics and oxygen were administered; and intake of fluid was restricted. The pulmonary, renal, hepatic, and haematological functions (table I) returned to normal over the next two weeks, and further recovery was complete and uneventful.

The patient had helped with lambing on the farm during January and February, especially with difficult deliveries needing intrauterine manipulation. Five of the 200 pregnant ewes had aborted, and one of the serum samples collected from three of the five had shown high antibody titres to antigens of toxoplasma and chlamydia. The patient had also fed flocks of turkeys and hens, but none of these had shown clinical illness.

\section{Microbiological investigations}

NON-CHLAMYDIAL ORGANISMS

No appreciable bacterial growth was found in samples of the patient's throat, urine, or repeated blood cultures, but Candida albicans was cultured from the throat and Streptococcus faecium from a high vaginal swab. Serological tests for leptospirosis, listeriosis (types 1 and 4), brucellosis, toxoplasmosis, Q fever, and infection with mycoplasma yielded negative results (apart from a titre of $1 / 20$ against Brucella abortus in the Coombs test) as did complement fixation tests against the following viruses: influenza $A$ and $B$ virus, respiratory syncytial virus, cytomegalovirus, and herpes simplex virus. Antibody against adenovirus was present but of constant titre (1/128). Samples 
taken from the infant's ears, umbilicus, cerebrospinal fluid, liver, lung, spleen, and meninges did not yield any appreciable bacterial growth, but Escherichia coli was cultured from the nose and throat and small numbers of both $E$ coli and Bacteroides melaninogenicus from the placental surfaces. Toxoplasma gondii was not isolated by inoculation in mice of samples of the infant's liver, lung, spleen, and meninges, and no virus was isolated from the placenta.

\section{CHLAMYDIA}

Table II shows the serological findings when the patient's serum samples were tested against various chlamydial antigens. Samples collected on 4 and 8 March showed a pronounced rise in antibody titre in complement fixation tests against chlamydial group antigen, which is prepared from ovine strains of $C$ psittaci. found with avian strains of $C$ psittaci but similar to that of ovine strains, and all gave strongly positive immunofluorescence with a rabbit antiserum that had been prepared against a current ovine strain (ZC31) and specifically absorbed against an avian strain of $C$ psittaci. The requirements for growth of the placental and fetal strains for all but tryptophan in a panel of amino acids ${ }^{4}$ were the same as those of the known ovine abortion strains A22 and ZC126 of $C$ psittaci but different from those of avian and ovine enteric strains.

Serological investigations (table II) showed that the titre of complement fixing antibody to chlamydial group antigen, having risen during the acute phase of the illness from $1 / 64$ to $1 / 512$, remained high two months later. Furthermore, tests performed in tissue culture showed rising titres of neutralising antibody against chlamydial isolates from the infant and placenta and also against a known ovine abortion, but not a known avian, strain of $C$ psittaci. By immunofluorescence there was a rise in the titre of $\mathrm{IgG}$ against known ovine

TABLE I-Biochemical and haematological investigations

\begin{tabular}{|c|c|c|c|c|c|c|}
\hline & \multicolumn{5}{|c|}{ Date of serum sample } & \multirow[b]{2}{*}{ Normal range } \\
\hline & 4 March & $6 \mathrm{March}$ & 9 March & 13 March & 18 March & \\
\hline $\begin{array}{l}\text { Sodium }(\mathrm{mmol} / \mathrm{l}) \\
\text { Potassium }(\mathrm{mmol} / \mathrm{l}) \\
\text { Bicarbonate }(\mathrm{mmol} / \mathrm{l}) \\
\text { Urea }(\mathrm{mmol} / \mathrm{l}) \\
\text { Creatinine }(\mu \mathrm{mol} / \mathrm{l}) \\
\text { Aspartate aminotransferase }(\mathrm{U} / \mathrm{l}) \\
\text { Albumin }(\mathrm{g} / \mathrm{l}) \\
\text { Alkaline phosphatase }(\mathrm{U} / \mathrm{l}) \\
\text { Haemoglobin }(\mathrm{g} / \mathrm{dl}) \\
\text { White cell count }\left(\times 10^{9} / \mathrm{l}\right) \\
\text { Platelet count }\left(\times 10^{9} / \mathrm{l}\right) \\
\text { Prothrombin time }(\mathrm{s}) \\
\text { Activated partial thromboplastin time }(\mathrm{s}) \\
\text { Thrombin clotting time }(\mathrm{s}) \\
\text { Fibrin degradation products }(\mathrm{mg} / \mathrm{l})\end{array}$ & $\begin{array}{c}12.5 \\
7.9 \\
18 \\
19.2 \\
73.5 \\
13.0 \\
>40\end{array}$ & $\begin{array}{c}124 \\
3 \cdot 7 \\
13 \\
33 \cdot 2 \\
610 \\
82 \\
26 \\
112 \\
9 \cdot 2 \\
7 \cdot 5 \\
48 \\
12 \cdot 8 \\
44 \cdot 0 \\
10 \cdot 2 \\
>40\end{array}$ & $\begin{array}{c}132 \\
3 \cdot 8 \\
14 \\
47 \cdot 8 \\
758+ \\
28 \\
28 \\
191 \\
10 \cdot 7 \\
7 \cdot 9 \\
53 \\
12 \cdot 5 \\
46 \cdot 0 \\
10 \cdot 0 \\
>10,<40\end{array}$ & $\begin{array}{c}137 \\
4 \cdot 5 \\
16 \\
28 \cdot 9 \\
347 \\
12 \\
31 \\
146 \\
10 \cdot 0 \\
12 \cdot 0 \\
351\end{array}$ & $\begin{array}{c}143 \\
4 \cdot 1 \\
23 \\
<2 \cdot 5 \\
83 \\
18 \\
44 \\
68 \\
10 \cdot 4 \\
7 \cdot 6 \\
311\end{array}$ & $\begin{array}{l}133-144 \\
3 \cdot 5-4 \cdot 9 \\
22-30 \\
3 \cdot 4-7 \cdot 0 \\
60-110 \\
<31 \\
37-47 \\
30-100 \\
14 \cdot 0(2 \cdot 0) \\
7 \cdot 0(3 \cdot 0) \\
150-450 \\
12-16 \\
35-45 \\
10(1 \cdot 0) \\
<10\end{array}$ \\
\hline
\end{tabular}

* Value on 5 March.

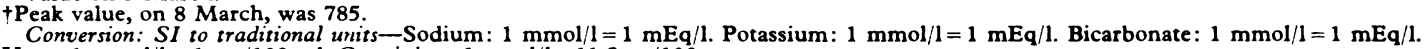

Urea: $1 \mathrm{mmol} / 1 \approx 6 \mathrm{mg} / 100 \mathrm{ml}$. Creatinine: $1 \mu \mathrm{mol} / 1=11.3 \mu \mathrm{g} / 100 \mathrm{mg}$.

TABLE II-Serological findings in serial samples tested against various chlamydial antigens

\begin{tabular}{|c|c|c|c|c|c|c|c|c|c|}
\hline \multirow{3}{*}{$\begin{array}{l}\text { Date of } \\
\text { sample }\end{array}$} & \multirow{3}{*}{$\begin{array}{c}\text { Complement } \\
\text { fixation titre } \\
\text { to chlamydial } \\
\text { group antigen }\end{array}$} & \multicolumn{5}{|c|}{ Immunofluorescence $†$ against: } & \multicolumn{3}{|c|}{ Neutralisation $\dagger$ against: } \\
\hline & & \multicolumn{2}{|c|}{ Ovine abortion strain } & \multicolumn{2}{|c|}{ Ovine enteric strain } & \multirow{2}{*}{$\underset{C \text { trachomatis }}{\text { Human genital }}$} & \multirow{2}{*}{$\begin{array}{l}\text { Chlamydia from human } \\
\text { placenta and } \\
\text { fetal blood }\end{array}$} & \multirow{2}{*}{$\begin{array}{c}\text { ZC 126 } \\
\text { ovine abortion } \\
\text { strain }\end{array}$} & \multirow{2}{*}{$\begin{array}{c}\text { Avian } \\
\text { (pigeon) } \\
\text { strain }\end{array}$} \\
\hline & & IgG & IgM & IgG & IgM & & & & \\
\hline $\begin{array}{l}4 \text { March } \\
8 \text { March } \\
9 \text { May }\end{array}$ & $\begin{array}{r}64 \\
512 \\
256\end{array}$ & $\begin{array}{c}+ \\
++++ \\
++++\end{array}$ & $\begin{array}{l} \pm \\
++ \\
++\end{array}$ & $\begin{array}{l} \pm \\
++ \\
++\end{array}$ & $\begin{array}{l}- \\
\overline{-}\end{array}$ & $\begin{array}{l}- \\
+ \\
+\end{array}$ & $\begin{array}{r}8 \\
32 \\
>64\end{array}$ & $\begin{array}{r}4 \\
16 \\
>64\end{array}$ & - \\
\hline
\end{tabular}

* Ovine abortion strain A22.

+Tested in tissue culture infected with strains indicated.

$C$ trachomatis was not isolated from cervical or high vaginal swabs or from fetal organs or placenta, but at Raigmore Hospital, Inverness, chlamydial inclusions developed in McCoy cell cultures inoculated with suspensions of fetal liver and lung but not with suspensions of fetal spleen. For confirmation and characterisation the original suspensions of fetal organs, together with suspensions of McCoy cells positive for chlamydia obtained by passage from these organs, were sent to the Veterinary Field Station, University of Liverpool. To avoid cross contamination these suspensions, along with serum obtained from the fetal heart and histological sections and homogenates of placenta sent directly from Aberdeen, were examined on separate occasions in a specially decontaminated isolation laboratory.

At the Veterinary Field Station elementary bodies of chlamydia were detected in smears of fetal liver, lung, and placenta using a fluorescein labelled rabbit antiserum against ovine strains of $C$ psittaci. Sections of placenta showed many chlamydial intracellular inclusions that were stained specifically by this antiserum. Chlamydia was isolated in McCoy cell culture directly from serum obtained from the fetal heart $\left(1.3 \times 10^{6}\right.$ inclusion forming units/1) and the placenta (> $9.6 \times 10^{5}$ inclusion forming units $/ \mathrm{g}$ ). Chlamydia was also reisolated from the McCoy cell cultures inoculated with the fetal material in Inverness. All the chlamydial isolates had the general characteristics of $C$ psittaci. Serial growth cycles, densely packed large inclusions, and absence of glycogen matrix differentiated them from $C$ trachomatis. Growth of the isolates in McCoy cell culture was slower than is usually abortion and ovine enteric strains of $C$ psittaci, with a higher titre against the abortion strain, and a smaller rise in the titre of IgM against only the ovine abortion strain. There was only a slight rise in antibody against a genital strain of $C$ trachomatis.

In July samples from remaining sheep and hens on the farm were examined. $C$ psittaci was isolated from the faeces of one of 19 ewes and three of five lambs but from none of four hens. High titres of antibody against the ZC126 ovine abortion strain of $C$ psittaci were detected by immunofluorescence and complement fixation techniques in six of 20 sheep. Swabs from the cervix, urethra, and throat of our patient and the urethra and throat of her husband two months after the abortion did not yield either $C$ trachomatis or $C$ psittaci.

\section{Histopathological investigations}

Necropsy of the fresh, stillborn fetus and placenta did not show any macroscopic abnormality. Histological examination did not show any foci of fetal infection in liver, spleen, or lungs. The placenta showed a pronounced acute inflammatory infiltrate in the intervillus spaces (fig 1). Fetal response was confined to early inflammatory changes around villus stem vessels. No other evidence of amnionitis was detected. Large, dense, intracytoplasmic inclusion bodies, characteristic of $C$ psittaci, were seen in cells of the syncytiotrophoblast and cyto- 
trophoblast on staining with haematoxylin and eosin, Giemsa, and methylene blue. Glycogen matrix was not present (Lugol's iodine stain). Inclusions were stained specifically for chlamydial antigen by a direct technique using immunoperoxidase and, on electron microscopy, were seen to be packed with chlamydial elementary and reticulate bodies with occasional intermediate forms (fig 2 ).

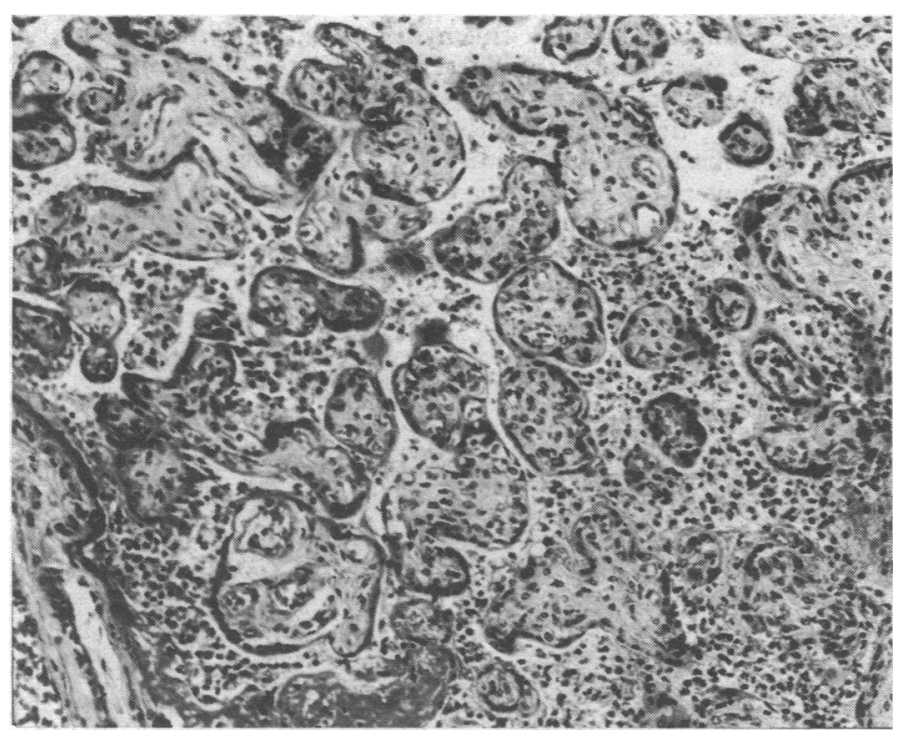

FIG 1-Acute placentitis with intervillus inflammatory exudate. Haematoxylin and eosin $\times 168$ (original magnification).

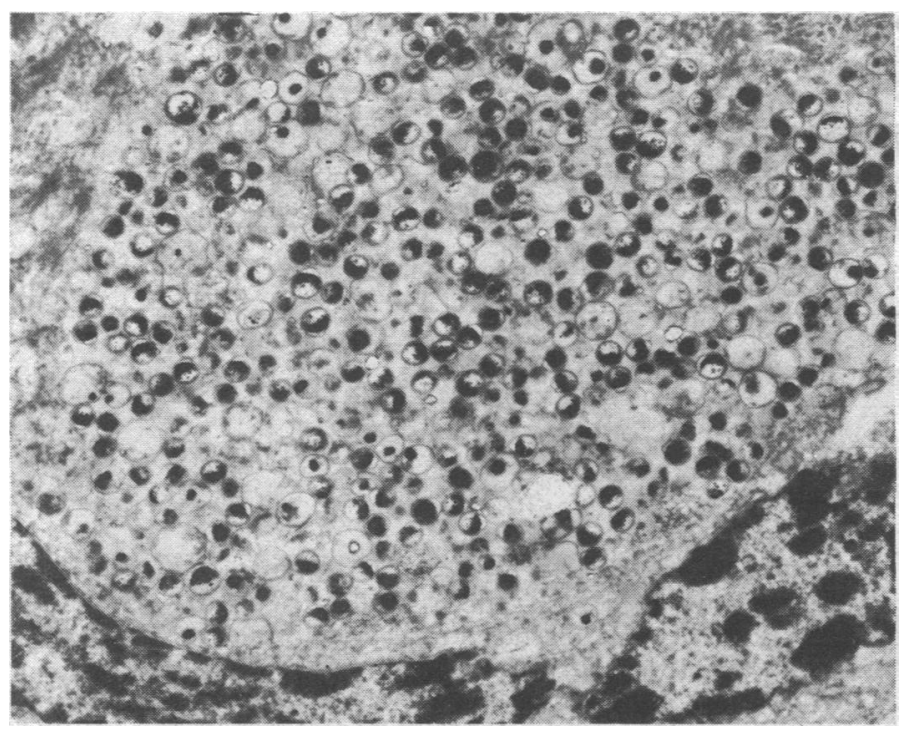

FIG 2-Syncytiotrophoblast cell with chlamydial inclusion densely packed with elementary and reticulate bodies. Osmium tetroxide, uranyl acetate, and lead citrate $\times 7000$ (original magnification).

\section{Discussion}

These findings show a causal link between an initially mild infection with $C$ psittaci in a pregnant woman and blood borne placentitis with resulting abortion. Epidemiological and microbiological evidence suggests that the organism was transmitted from farm animals and was probably an ovine strain associated with enzootic abortion on the patient's farm. ${ }^{5}$ An avian source of infection seems unlikely but requires further investigation. ${ }^{6}$ ?

The pathogenesis of the maternal disease is not clear. Infection within flocks of sheep in which chlamydial abortion has occurred may be maintained between lambing seasons by enteric spread from infected ewes to lambs, and subsequently between lambs, to give a persistent but mainly subclinical gut infection. Placental infection, when the ewes mature and become pregnant, might arise by the selection of variants with affinity for the placenta from the pre-existing enteric infection. Organisms isolated from the placenta (abortion strains) resemble those in the gut (enteric strains) but show minor differences in biotype and serology that aid their identification. ${ }^{8}$ No evidence exists for a similar pattern of infection in man, although the rapid onset of a secondary immune response (IgG) in our patient was surprising. Further work is needed on the affinity of chlamydia for the placenta and on the detailed pathogenesis and extent of abortion induced by chlamydia in women. Whether the delayed shock in our patient was immunologically mediated ${ }^{\circ}$ or due to some other cause $\mathrm{i}^{10}$ also requires further investigation. Finally, data from this and similar cases should be collated to define any clinical homogeneity or variation that may emerge for this syndrome.

Doctors must be made aware of the possible risk to pregnant women in rural areas where chlamydial infections of farm animals are widespread." Such women should be advised against close contact with animals during their pregnancy and, especially, helping with sheep during the lambing season. If clinically similar cases occur medical attendants should recognise that confirmatory laboratory tests are available, including tests for complement fixing antibodies to chlamydia and, in cases of abortion, the simple microscopic examination of smears of the placenta stained with Giemsa. Chlamydial infections respond readily to erythromycin, which would be preferred to the tetracyclines during pregnancy, but poorly to penicillins and cephalosporins.

We thank many clinical, veterinary, and laboratory colleagues for advice and help during the management and investigation of this case, especially Mr W Murchie, veterinary surgeon, Ellon; Dr A G Taylor, Central Public Health Laboratory, Colindale, London; Dr I D Aitken and Dr D Buxton, Animal Diseases Research Association, Moredun Institute, Edinburgh; and Dr C C Smith, City Hospital and Aberdeen Royal Infirmary, Aberdeen.

\section{References}

1 Giroud P, Roger F, Dumas N. Certains avortements chez la femme peuvent être dus à dés agents situés à côté du groupe de la psittacose. Comptes Rendus Heb domadaires des Séances de l'Académie des Sciences 1956;242:697-9. Roberts W, Grist NR, Giroud P. Human aborti

3 Beer RJS, Bradford WP, Hart RJC. Pregnancy complicated by psittacosis acquired by sheep. Br Med F 1982;284:1156-7.

4 Johnson FWA. Isolation of Chlamydia psittaci from nasal and conjunctival exudate of a domestic cat. Vet Rec 1984;114:342-4.

5 Blewett DA, Gisemba F, Miller JK, Johnson FWA, Clarkson MJ. Ovine enzootic bortion: the acquisition of infection and consequent abortion within a single 9-501.

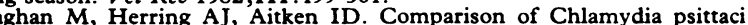
isolates by DNA restriction endonuclease analysis. Infect Immun 1984;45:384Anonymous. Psittacosis of non-avian origin [Editorial]. Lancet 1984;ii :442-3. 8 Johnson FWA. Enteric infection in sheep associated with abortion. Irish Veterin-

Braude AI. Mechanisms of immunologic injury in infectious diseases. In: Braude AI, Davis CE, Fierer J, eds. Medical microbiology and infectious diseases. Philadelphia: W B Saunders, 1981:761-70

10 Heineman HS. Shock in infectious diseases. In: Braude AI, Davis CE, Fierer J, eds. Medical microbiology and infectious diseases. Philadelphia: W B Saunders, 1 Johnson FWA. Chlamydiosis. Br Vet f 1983;139:93-101.

(Accepted 5 December 1984) 